\title{
ANALISIS HUBUNGAN KARAKTERISTIK ANAK DAN LINGKUNGAN KELUARGA DENGAN PERILAKU BULLYING
}

\author{
Yeni Devita $^{1)}$, Fitri Dyna ${ }^{2)}$ \\ ${ }^{1,2}$ Program Studi S1 Keperawatan STIKes Payung Negeri Pekanbaru \\ yenidevita@payungnegeri.ac.id
}

Diterima: September 2018 Diterbitkan: Desember 2018

\begin{abstract}
Abstrak
Bullying dikalangan anak sekolah merupakan sebuah fenomena yang sudah lama terjadi. Banyak alasan yang menyebabkan seseorang melakukan tindakan bullying, bisa dari individu anak itu sendiri dan lingkungan keluarga anak. Tujuan penelitian ini untuk menganalisis hubungan karakteristik anak dan lingkungan keluarga dengan perilaku bullying. Jenis penelitian ini kuantitatif dengan desain korelasional. Lokasi penelitian di seluruh SD Negeri di Kota Pekanbaru. Populasi nyaadalah seluruh siswa SD Negeri yang berada di Kota Pekanbaru dengan sampel sebanyak 400 siswa sekolah dasar negeri. Hasil penelitian menunjukkan bahwa ada hubungan antara umur, jenis kelamin, kelas, pekerjaan ibu, media kekerasan, perkelahian, dan makian dengan perilaku bullying pada anak usia sekolah. Sedangkan untuk variabel kepunyaan geng, pola asuh orang tua, dan pekerjaan ayah tidak memiliki hubungan yang signifikan dengan perilaku bullying pada anak usia sekolah. Hasil analisis multivariat menunjukkan bahwa variabel kelas responden mempunyai hubungan yang paling kuat dengan perilaku bullying pada anak usia sekolah. probabilitas anak usia sekolah untuk melakukan perilaku bullying adalah $12 \%$. Hasil penelitian ini dapat dijadikan acuan bagi pihak sekolah untuk mencegah terjadinya perilaku bullying. Untuk para orang tua dan keluarga dapat meminimalkan faktor-faktor lingkungan keluarga yang dapat memicu terjadinya perilaku bullying seperti media kekerasan, perkelahian dan makian di lingkungan keluarga
\end{abstract}

Kata Kunci: Karakteristik Anak, Lingkungan Keluarga, Perilaku Bullying, Anak Usia Sekolah

\begin{abstract}
Bullying among school children is a phenomenon that has long occurred. There are many reasons that cause a person to do bullying, it can be from the individual child himself and the child's family environment. This study aims to monitor the relationship of children with students in public elementary schools. This type of research is quantitative with correlational design. The location of this research is all public elementary schools. The population in this study were all students of public elementary schools with a sample of 400 public elementary school students. The results showed that there was a relationship between age, sex, class, mother's work, media of violence, fighting, and abuse with bullying behavior in school children. Whereas for the variables belonging to the gang, parenting parents, and father's work do not have a significant relationship with bullying behavior in school children. The results of multivariate analysis showed that the respondent variables had the strongest relationship with bullying behavior in school children. the probability of school children to do bullying behavior is $12 \%$. For parents and families can include family environmental factors that can be used for bullying behavior such as media violence, fighting and abuse in the family.
\end{abstract}

Keywords: characteristics of children, family environment, bullying behavior, school children 


\section{PENDAHULUAN}

Bullying dikalangan anak sekolah merupakan sebuah fenomena yang sudah lama terjadi dan merupakan masalah serius yang membutuhkan perhatian. Bullying disekolah biasanya terjadi akibat kurang atau tidak adanya pengawasan. Bullying biasanya terjadi disekitar lingkungan sekolah seperti dikelas saat kerja kelompok, kamar mandi, loronglorong atau setelah kegiatan sekolah(Shariff, 2008). Bullying merupakan perilaku agresif yang dilakukan oleh seseorang yang memiliki kekuasaan dan kekuatan kepada orang yang lebih lemah secara sengaja dan dilakukan secara terus menerus baik secara fisik maupun non fisik(Swearer, Espelage, \& Napolitano, 2009).

Hasil survei di Amerika Serikat melaporkan sebanyak 2.027.254 anak sekolah mengalami kejadian bullying kategori moderat dan 1.681 .030 anak sekolah mengalami kejadian bullying kategori sering. Perilaku bullying pada anak usia sekolah di Amerika Serikat digolongkan sebagai 1 dari 10 masalah kesehatan yang sering terjadi pada anak sekolah(Namie, Christensen, \& Phillips, 2014). Riset yang dilakukan LSM Plan International dan International Center for Research on Women (ICRW) yang dilansir oleh liputan6.com tahun 2015 menunjukkan bahwa terdapat $70 \%$ anak di Asia dan 84\% anak di Indonesia mengalami kekerasan disekolah. Kasus bullying yang diterima Komisi Perlindungan Anak di Indonesia terjadi peningkatan sejak tahun 2010 hingga 2014 diantaranya 2.413, 2.508, 2.637, 2.792, dan 3.339 kasus pada tahun 2014(Andina, 2014). Jumlah anak sebagai pelaku kekerasan (bullying) di sekolah mengalami kenaikan dari 67 kasus pada 2014 menjadi 79 kasus di 2015.

Hasil penelitian yang dilakukan oleh Hertinjung \& Karyani menunjukkan bahwa prevalensi bullying pada siswa
Sekolah Dasar di Surakarta adalah 47\% terlibat dalam bullying dan $48 \%$ rentan untuk terlibat dalam bullying(Hertinjung \& Karyani, 2015). Penelitian yang dilakukan oleh Nurhamzah, Maureen, \& Wiguna menunjukkan hasil bahwa 89,5\% anak sekolah dasar di Sekolah Dasar Negeri Cikini 02 Pagi dan Sekolah Dasar Swasta Tunas Bangsa pernah terlibat dalam perilaku bullying. Bullying paling sering terjadi di ruang kelas pada waktu istirahat sekolah(Nurhamzah, Maureen, \& Wiguna, 2013).

Sekolah yang seharusnya menjadi tempat bagi anak menimba ilmu serta membantu membentuk karakter pribadi yang baik ternyata menjadi tempat praktik bullying. Akibatnya akan berdampak kepada anak seperti kesepian, pencapaian akademik yang buruk, kesulitan beradaptasi, keterlibatan dalam tindakan kriminal dan kerentanan gangguan mental emosional seperti cemas, insomnia, dan depresi yang dapat berlanjut dan menetap sampai dewasa(Rigby, 2011). Banyak alasan yang menyebabkan seseorang melakukan tindakan bullying, bisa dari individu anak itu sendiri dan lingkungan keluarga anak. Lingkungan keluarga dapat memicu untuk terjadinya tindakan bullying. Lingkungan rumah seringkali dianggap sebagai tempat sosialisasi pertama dan utama bagi anak(Beane, 2008). Lingkungan keluarga seperti pola asuh orang tua sangat berpengaruh terhadap perilaku anak. Anak yang berada dilingkungan keluarga yang cenderung berperilaku kearah negatif seperti sering terjadi kekerasan, memaki dengan katakata kotor, menonton tv dengan adegan kekerasan dapat berimbas pada perilaku anak dan beresiko untuk melakukan tindakan bullying(Storey et al., 2013).

Wawancara yang dilakukan oleh peneliti kepada beberapa guru yang berada di Sekolah Dasar Negeri di Pekanbaru mengatakan bahwa ada anak muridnya yang terlibat kasus bullying bahkan ada yang sampai pindah sekolah karena takut dibulli oleh teman-temannya. 
Kejadian bullying pada sekolah dasar negeri di kota Pekanbaru belum dapat perhatian oleh pihak pemerintah. Padahal di Pekanbaru telah tersedia puskesmas dan program usaha kesehatan sekolah (UKS) disetiap sekolah serta guru bimbingan konseling. Belum terdapatnya suatu program atau upaya yang berkaitan dengan bullying, berdampak pada tidak tersedianya angka kejadian bullying pasti pada anak usia Sekolah Dasar Negeri di Pekanbaru Riau. Tujuan penelitian ini bertujuan untuk mengidentifikasi dan menganalisis hubungan karakteristik anak dan lingkungan keluarga dengan perilaku bullying pada anak usia sekolah di Sekolah Dasar Negeri Se Kota Pekanbaru Riau.

\section{METODE PENELITIAN}

Jenis penelitian ini adalah penelitian kuantitatif dengan rancangan korelasional. Populasi dalam penelitian ini adalah seluruh siswa kelas 4 dan 5 yang berada di seluruh Sekolah dasar Negeri Se Kota pekanbaru. Sampel dalam penelitian ini berjumlah 400 anak usia sekolah. Pengambilan sampel dalam penelitian ini menggunakan teknik cluster sampling. Alat pengumpul data dengan menggunakan kuesioner yang terdiri dari data demografi (usia, jenis kelamin, kelas, serta pernyataan apakah memiliki geng disekolah atau tidak) dan kejadian bullying. Analisa data menggunakan uji chi square untuk analisa bivariate dan menggunakan uji regresi logistic untuk analisa multivariat.

\section{HASIL DAN PEMBAHASAN \\ HASIL PENELITIAN}

\subsection{Analisis Bivariat}

Analisis bivariat digunakan untuk menjelaskan hubungan antara variabel independen dengan variabel dependen. Variabel dependen yaitu karakteristik anak dan lingkungan keluarga, variabel dependen yaitu perilaku bullying.
Tabel 5.5. Hubungan Umur Responden Dengan Perilaku Bullying Pada Anak

Usia Sekolah Di Sekolah Dasar

Negeri Se Kota Pekanbaru

\begin{tabular}{|c|c|c|c|c|}
\hline \multirow{3}{*}{ Umur } & $\begin{array}{l}\text { Perilaku } \\
\text { bullying }\end{array}$ & $\mathrm{n}$ & $\begin{array}{l}\text { Min - } \\
\text { Maks }\end{array}$ & $\mathrm{p}$ Value \\
\hline & $\mathrm{Ya}$ & 212 & \multirow{2}{*}{$9-14$} & \multirow{2}{*}{0,000} \\
\hline & Tidak & 188 & & \\
\hline
\end{tabular}

Hasil analisis mann-whitney umur responden diperolah angka $\mathrm{p}$ value nya adalah 0,000 . Karena nilai $p$ value $<0,05$ dapat disimpulkan bahwa terdapat hubungan antara umur responden dengan perilaku bullying pada anak usia sekolah.

Tabel 5.6. Hubungan jenis kelamin, kelas, dan geng dengan perilaku bullying pada anak usia sekolah di sekolah dasar negeri se kota pekanbaru

\begin{tabular}{|c|c|c|c|c|c|c|c|}
\hline & & \multicolumn{4}{|c|}{ Perilaku Bullying } & \multirow{3}{*}{$\begin{array}{c}\mathrm{P} \\
\text { val } \\
\text { ue }\end{array}$} & \multirow{3}{*}{ OR } \\
\hline & & \multicolumn{2}{|c|}{$\mathrm{Ya}$} & \multicolumn{2}{|c|}{ Tidak } & & \\
\hline & & $\mathrm{n}$ & $\%$ & $\mathrm{n}$ & $\%$ & & \\
\hline \multirow{3}{*}{$\begin{array}{l}\text { Jenis } \\
\text { Kela } \\
\text { min }\end{array}$} & Laki & 110 & 66,7 & 55 & 33,3 & \multirow{3}{*}{$\begin{array}{c}0,0 \\
00\end{array}$} & \multirow{3}{*}{$\begin{array}{c}2,60 \\
8\end{array}$} \\
\hline & $\overline{\text { Laki }}$ & & & & & & \\
\hline & $\begin{array}{l}\text { Pere } \\
\text { mpua } \\
\mathrm{n}\end{array}$ & 102 & 43,4 & 133 & 56,6 & & \\
\hline \multirow[t]{2}{*}{ Kelas } & $\begin{array}{l}\text { Kelas } \\
4\end{array}$ & 99 & 47,6 & 109 & 52,4 & \multirow{2}{*}{$\begin{array}{c}0,0 \\
31\end{array}$} & \multirow{2}{*}{$\begin{array}{c}0,63 \\
5\end{array}$} \\
\hline & $\begin{array}{l}\text { Kelas } \\
5\end{array}$ & 113 & 58,9 & 79 & 41,1 & & \\
\hline \multirow[t]{2}{*}{ Geng } & $\begin{array}{l}\text { Mem } \\
\text { iliki }\end{array}$ & 68 & 58,6 & 48 & 41,4 & \multirow[b]{2}{*}{$\begin{array}{l}0,1 \\
84\end{array}$} & \multirow[b]{2}{*}{$\begin{array}{c}1,37 \\
7\end{array}$} \\
\hline & $\begin{array}{l}\text { Tida } \\
\mathrm{k} \\
\text { Mem } \\
\text { iliki }\end{array}$ & 144 & 50,7 & 140 & 49,3 & & \\
\hline
\end{tabular}

Hasil analisis hubungan karakteristik anak dengan perilaku bullying didapatkan hasil bahwa jenis kelamin dan kelas memiliki hubungan yang signifikan dengan perilaku bullying dengan $p$ value $<0,05$. Hasil uji statistic menunjukkan bahwa kelas 5 s memiliki peluang sebanyak 0,635 kali melakukan perilaku bullying dan yang memiliki geng bepeluang sebanyak 1,377 kali melakukan perilaku bullying. 
Tabel 5.7. Hubungan lingkungan keluarga dengan perilaku bullying pada anak usia sekolah di sekolah dasar negeri se kota pekanbaru

\begin{tabular}{|c|c|c|c|c|c|c|c|}
\hline & & \multicolumn{4}{|c|}{ Perilaku Bullying } & \multirow{3}{*}{$\begin{array}{c}\mathrm{P} \\
\text { val } \\
\text { ue }\end{array}$} & \multirow{3}{*}{ OR } \\
\hline & & \multicolumn{2}{|c|}{$\mathrm{Ya}$} & \multicolumn{2}{|c|}{ Tidak } & & \\
\hline & & $\mathrm{n}$ & $\%$ & $\mathrm{n}$ & $\%$ & & \\
\hline \multirow{7}{*}{$\begin{array}{l}\text { Pola } \\
\text { Asuh } \\
\text { Orang } \\
\text { Tua }\end{array}$} & Parenta & 93 & 54, & 79 & 45,9 & \multirow{7}{*}{$\begin{array}{l}0,7 \\
86\end{array}$} & \multirow{7}{*}{$\begin{array}{l}1,0 \\
78\end{array}$} \\
\hline & & & 1 & & & & \\
\hline & Warmt & & & & & & \\
\hline & $\mathrm{h}$ & & & & & & \\
\hline & Parenta & 119 & 52 , & 109 & 47,8 & & \\
\hline & & & 2 & & & & \\
\hline & Control & & & & & & \\
\hline \multirow{3}{*}{$\begin{array}{c}\text { Pekerj } \\
\text { aan } \\
\text { Ayah }\end{array}$} & Formal & 84 & 51 , & 78 & 48,1 & \multirow{3}{*}{$\begin{array}{c}0,7 \\
81\end{array}$} & \multirow{3}{*}{$\begin{array}{l}0,9 \\
25\end{array}$} \\
\hline & Non & 128 & $\begin{array}{r}9 \\
53\end{array}$ & & 462 & & \\
\hline & Formal & & $\begin{array}{c}55, \\
8\end{array}$ & & & & \\
\hline \multirow{4}{*}{$\begin{array}{l}\text { Pekerj } \\
\text { aan } \\
\text { Ibu }\end{array}$} & Bekerja & 93 & 46 , & 106 & 53,3 & \multirow{4}{*}{$\begin{array}{r}0,0 \\
16\end{array}$} & \multirow{4}{*}{$\begin{array}{c}0,6 \\
05\end{array}$} \\
\hline & & & 7 & & & & \\
\hline & Tidak & 119 & 59 , & 82 & 40,8 & & \\
\hline & Bekerja & & 2 & & & & \\
\hline \multirow{3}{*}{$\begin{array}{l}\text { Media } \\
\text { Keker } \\
\text { asan } \\
(\mathrm{TV})\end{array}$} & $\mathrm{Ya}$ & 80 & 71 , & 32 & 28,6 & \multirow{3}{*}{$\begin{array}{c}0,0 \\
00\end{array}$} & \multirow{3}{*}{$\begin{array}{r}2,9 \\
55\end{array}$} \\
\hline & & & 4 & & & & \\
\hline & Tidak & 132 & $\begin{array}{c}45 \\
8\end{array}$ & 156 & 54,2 & & \\
\hline \multirow{3}{*}{$\begin{array}{l}\text { Perkel } \\
\text { ahian }\end{array}$} & $\mathrm{Ya}$ & 93 & 68 , & 42 & 31,1 & \multirow{3}{*}{$\begin{array}{c}0,0 \\
00\end{array}$} & \multirow{3}{*}{$\begin{array}{r}2,7 \\
17\end{array}$} \\
\hline & Tidak & 110 & 44 & 146 & 551 & & \\
\hline & 11dак & 119 & $\begin{array}{c}44, \\
9\end{array}$ & 140 & JJ, & & \\
\hline \multirow{3}{*}{$\begin{array}{l}\text { Makia } \\
\mathrm{n}\end{array}$} & $\mathrm{Ya}$ & 56 & 72 , & 21 & 27,3 & \multirow{3}{*}{$\begin{array}{c}0,0 \\
00\end{array}$} & \multirow{3}{*}{$\begin{array}{c}2,8 \\
55\end{array}$} \\
\hline & & & 7 & & & & \\
\hline & Tidak & 156 & $\begin{array}{c}48, \\
3\end{array}$ & 167 & 51,7 & & \\
\hline
\end{tabular}

Hasil analisis hubungan antara lingkungan keluarga dengan perilaku bullying diperoleh hasil bahwa ada hubungan antara pekerjaan ibu, media kekerasan, perkelahian, dan makian dengan perilaku bullying dengan $p$ value $<0,05$. Hasil uji statistik menunjukkan bahwa perilaku bullying berpeluang sebanyak 0,6 kali terjadi pada responden dengan ibu yang bekerja, 2,955 kali berpeluang terjadi perilaku bullying pada anak yang melihat perilaku bullying dari media televise, 2,717 kali berpeluang dari perkelahian, dan berpeluang sebanyak 2,855 kali dari makian.

\subsection{Analisis multivariat}

Analisis multivariat bertujuan untuk menentukan hubungan antara varianel dependen dan variabel dependen.
1.2.1. Model Multivariat

Tabel 5.8. Analisis Multivariat

Karakteristik Anak, Lingkungan

Keluarga, Dan Perilaku Bullying Pada

Anak Usia Sekolah Di Sekolah Dasar

Negeri Se Kota Pekanbaru

\begin{tabular}{|c|c|c|c|c|}
\hline $\begin{array}{c}\text { Lang } \\
\text { kah }\end{array}$ & Variabel & $\begin{array}{c}\text { Koefesi } \\
\text { en }\end{array}$ & $\begin{array}{c}\mathrm{P} \\
\text { value } \\
\end{array}$ & OR (IK95\%) \\
\hline \multirow[t]{7}{*}{$\begin{array}{l}\text { Lang } \\
\text { kah } 1\end{array}$} & $\begin{array}{l}\text { Jenis } \\
\text { kelamin }\end{array}$ & $-0,946$ & 0,000 & $\begin{array}{c}0,388(0,246- \\
0,613\end{array}$ \\
\hline & Kelas & 0,521 & 0.019 & $\begin{array}{c}1,684(1,090- \\
2,601)\end{array}$ \\
\hline & Geng & $-0,413$ & 0,097 & $\begin{array}{c}0,662(0,406- \\
1,078)\end{array}$ \\
\hline & $\begin{array}{l}\text { Pekerjaa } \\
\text { n Ibu }\end{array}$ & 0,515 & 0,019 & $\begin{array}{c}1,673(1,086- \\
2,576)\end{array}$ \\
\hline & $\begin{array}{l}\text { Media } \\
\text { Kekerasa } \\
\mathrm{n}\end{array}$ & $-0,640$ & 0.015 & $\begin{array}{c}0,527(0,314- \\
0,884)\end{array}$ \\
\hline & $\begin{array}{l}\text { Perkelahi } \\
\text { an }\end{array}$ & $-0,796$ & 0,002 & $\begin{array}{c}0,451(0,273- \\
0,745)\end{array}$ \\
\hline & Makian & $-0,650$ & 0,040 & $\begin{array}{c}0,522(0,281- \\
0,969)\end{array}$ \\
\hline
\end{tabular}

Hasil analisis regresi logistik menunjukkan bahwa ada enam variabel independen yang mempunyai nilai probabilitas kurang dari 0,05 . Ke enam variabel tersebutt yaitu jenis kelamin, kelas, pekerjaan ibu, media kekerasan, perkelahian, dan makian.

Hasil ini menunjukkan bahwa keenam variabel kandidat memenuhi signifikansi parsial. Model akhir ini menunjukkan bahwa variabel jenis kelamin, kelas, pekerjaan ibu, media kekerasan, perkelahian, dan makian merupakan variabel yang berpengaruh terhadap perilaku bullying pada anak usia sekolah. Variabel indpenden yang paling dominan berpengaruh terhadap perilaku bullying dari keenam variabel tersebut adalah kelas responden. Hal ini ditentukan berdasarkan nilai OR sebesar 1,684 yang lebih besar dari nilai OR variabel lainnya.

Persamaan dari model regresi logistik ini dapat dilihat sebagai berikut: 
$y=$ konstanta $+a_{1} x_{1}+a_{2} x_{2}+a_{3} x_{3}+$

$\mathrm{a}_{4} \mathrm{x}_{4}+\mathrm{a}_{5} \mathrm{x}_{5}+\mathrm{a}_{6} \mathrm{x}_{6}$

$y=0,392+(-0,946)($ Jenis Kelamin $)+$

0,521 (Kelas) $+(-0,515)$ (Pekerjaan Ibu)

$+(-0,640)($ Media Kekerasan $)+(-$

$0,796)($ Perkelahian $)+(-0,650)($ Makian $)$

untuk melihat nilai probabilitas anak usia sekolah melakukan perilaku bullying dapat dilihat dari persamaan sebagai berikut :

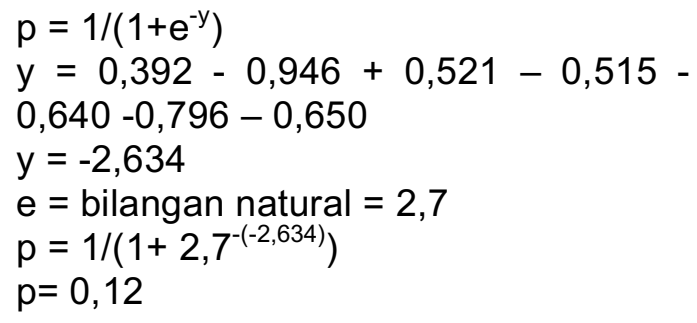

dengan demikian, probabilitas anak usia sekolah untuk melakukan perilaku bullying adalah $12 \%$.

\section{PEMBAHASAN}

1. Hubungan karakteristik anak dengan perilaku bullying pada anak usia sekolah

Hasil penelitian menunjukkan bahwa ada hubungan antara umur, jenis kelamin dan kelas dengan perilaku bullying, sedangkan untuk variabel kepunyaan geng tidak memiliki hubungan yang signifikan.

Rentang usia pada tahap anak sekolah adalah 6-12 tahun. Perkembangan Psikososial pada tahap usia sekolah berada pada tahap industri untuk yang normal dan tahap inferioritas untuk penyimpangan. Tahap usia anak sekolah rentan untuk mengalami kejadian bullying(Keliat, Tololiu, Daulima, \& Erawati, 2015). Anak yang berada pada usia sekolah mulai berinteraksi dan akan berusaha mencapai kompetensi. Keberhasilan dan kegagalan dalam mencapai kompetensi di sekolah dapat memicu anak untuk berperilaku bullying baik sebagai korban ataupun pelaku bullying. Hasil penelitian ini sejalan dengan penelitian Dewi menunjukkan bahwa jenis kelamin anak pada usia sekolah merupakan salah satu faktor terjadinya perilaku bullying(Dewi, 2014). Kejadian bullying pada anak laki-laki sebesar 78,7\% dan 63\% pada anak perempuan. $66 \%$ siswa laki-laki dan $86 \%$ siswa perempuan berperan langsung sebagai pelaku bullying. Tingkatan kelas juga mempunyai peran dalam perilaku bullying. Kakak kelas atau seniornya dalam sekolah biasanya memiliki kuasa dan kekuatan untuk melakukan tindakan bullying pada kelas yang tingkatannya lebih rendah. Kepemilikan geng pada anak tidak memiliki hubungan yang signifikan dengan perilaku bullying pada anak usia sekolah, hal ini terjadi karena pada masa pembentukan kelompok (geng) di sekolah anak akan mulai membentuk ikatan yang kuat dengan teman gengnya. Ikatan yang kuat didalam geng dapat meningkatkan kemampuan anak dalam bersosialisasi dan mencapai kemandirian, sehingga anak dalam geng tersebut akan mencari dukungan dari teman segengnya jika terjadi perilaku bullying pada dirinya, dan geng lain juga tidak akan berani untuk melakukan perbuatan bullying pada geng yang kuat tersebut.

2. Hubungan Lingkungan Keluarga dengan perilaku bullying pada anak usia sekolah

Hasil penelitian menunjukkan bahwa ada hubungan antara pekerjaan ibu, media kekerasan, perkelahian, dan makian dengan perilaku bullying, sedangkan untuk pekerjaan ayah dan pola asuh orang tua tidak memiliki hubungan yang signifikan dengan perilaku bullying. 
Hal ini sejalan dengan penelitian Rahmadara yang menunjukkan hasil bahwa tidak ada hubungan antara pola asuh orang tua dengan peran-peran dalam perilaku bullying pada pelajar sekolah dasar(Rahmadara, 2012). Hasil penelitian ini memiliki makna bahwa peran seseorang dalam perilaku bullying tidak terlalu dipengaruhi oleh pola asuh yang diberikan oleh orang tuanya. Media kekerasan, perkelahian dan makian memiliki hubungan yang signifikan dengan perilaku bullying, hal ini sesuai dengan hasil interview sederhana peneliti kepada beberapa responden yang sebagian besar mengatakan bahwa mereka mendapatkan ide untuk melakukan perilaku bullying dari acara televisi yang ditontonnya, dari lingkungan keluarga yang sering kali mendengar kata-kata kotor dari kakak dan abangnya, serta seringnya terjadi perkelahian antar saudaranya. Namun hal yang paling menentukan ide untuk melakukan perbuatan bullying adalah media televisi. Pekerjaan ibu juga memiliki hubungan dengan perilaku bullying, ibu yang bekerja akan memiliki keterbatasan dalam mengawasi dan mengontrol anaknya, sehingga anak akan rentan terlibat dalam perilaku bullying baik sebagai pelaku maupun sebagai korban. Hasil penelitian ini juga sejalan dengan penelitian yang dilakukan oleh Sufriani yang menunjukkan bahwa ada hubungan antara faktor keluarga dan faktor media dengan tindakan bullying pada anak usia sekolah(Sufriani \& Sari, 2017).

\section{SIMPULAN}

Hasil penelitian menunjukkan bahwa ada hubungan antara umur, jenis kelamin, kelas, pekerjaan ibu, media kekerasan, perkelahian, dan makian dengan perilaku bullying pada anak usia sekolah di sekolah dasar negeri se kota pekanbaru. Sedangkan untuk variabel kepunyaan geng, pola asuh orang tua, dan pekerjaan ayah tidak memiliki hubungan yang signifikan dengan perilaku bullying pada anak usia sekolah di sekolah dasar negeri se kota pekanbaru.

Hasil analisis multivariat menunjukkan bahwa variabel kelas responden mempunyai hubungan yang paling kuat dengan perilaku bullying pada anak usia sekolah. probabilitas anak usia sekolah untuk melakukan perilaku bullying adalah $12 \%$. Hasil penelitian ini dapat dijadikan acuan bagi pihak sekolah untuk mencegah terjadinya perilaku bullying pada anak usia sekolah. Untuk para orang tua dan keluarga dapat meminimalkan factorfaktor lingkungan keluarga yang dapat memicu terjadinya perilaku bullying seperti media kekerasan, perkelahian dan makian di lingkungan keluarga.

\section{UCAPAN TERIMAKASIH}

Peneliti mengucapkan terima kasih kepada Direktorat Riset dan Pengabdian Masyarakat Direktorat Jenderal Penguatan Riset dan Pengembangan Kementerian Riset, Teknologi, dan Pendidikan Tinggi yang telah membiayai penelitian ini. Usapan terima kasih juga diucapkan kepada semua pihak sekolah dasar negeri se kota pekanbaru yang telah memberikan izin penelitian dan semua pihak yang telah membantu dalam proses penelitian.

\section{DAFTAR PUSTAKA}

Andina, E. (2014). Budaya Kekerasan Antar Anak Di Sekolah Dasar, VI(9), 9-12.

Beane, A. L. (2008). Protect Your Child from Bullying.

Dewi, D. A. P. (2014). Gambaran Kejadian Dan Karakteristik Bullying Pada Anak Usia Sekolah Di Sekolah Dasar Wilayah Kerja Puskesmas I Pekutatan Kabupaten Jembrana Bali. Isainsmedis, 8(1), 1-9.

Hertinjung, W. S., \& Karyani, U. (2015). 2015 ISSN 2407-9189 The 2 nd 
University Research Coloquium 2015 ISSN 2407-9189. The $2 \mathrm{Nd}$ University Research Coloquium, (2011), 173-180.

Keliat, B. A., Tololiu, T. A., Daulima, N. H. C., \& Erawati, E. (2015). Effectiveness Assertive Training of Bullying Prevention among Adolescents in West Java Indonesia. International Journal of Nursing, 2(1), $128-134$ https://doi.org/10.15640/ijn.v2n1a14 Namie, G., Christensen, A. D., \& Phillips, D. (2014). Workplace Bullying Survey, 1-19.

Nurhamzah, W., Maureen, A., \& Wiguna, T. (2013). Gambaran Bullying dan Hubungannya dengan Masalah Emosi dan Perilaku pada Anak Sekolah Dasar, 15(3).

Rahmadara, B. (2012). Hubungan Antara Pola Asuh Orangtua dan Peran-Peran
Dalam Perilaku Bullying Pada Siswa Sekolah Dasar.

Rigby, K. (2011). Stop The Bullying A Handbook For Schools. Australia.

Shariff, S. (2008). Cyber-Bullying.

Storey, K., Slaby, R., Adler, M., Minotti, J., Katz, R., \& Storey, K. (2013). Eyes on Bullying Toolkit What Can You Do?

Sufriani, \& Sari, E. P. (2017). Faktor Yang Mempengaruhi Bullying Pada Anak Usia Sekolah Banda Aceh The Factors Affect Bullying on SchoolAge Children In Elementary Schools the Syiah Kuala Subdistrict In Banda Aceh. Idea Nursing Jurnal, VIII(3).

Swearer, S. M., Espelage, D. L., \& Napolitano, S. A. (2009). Bullying Prevention \& Intervention. Realistic Strategies For Schools. Canada. 